\title{
PENERAPAN KESEJAHTERAAN HEWAN PADA BEBERAPA PETERNAKAN AYAM RAS PEDAGING (STUDI KASUS DI KABUPATEN BANGKA)
}

\author{
Susanti 1), Nur Annis Hidayati'), Budi Afriyansyah' ${ }^{1)}$ \\ ${ }^{1}$ Mahasiswa Jurusan Biologi, FPPB, Universitas Bangka Belitung \\ Sue.santi@ymail.com \\ ${ }^{2}$ Dosen Jurusan Biologi, FPPB, Universitas Bangka Belitung \\ nurannishidayati@gmail.com
}

\begin{abstract}
Animal welfare is a less common issue in Bangka. Animal welfare is the well-being of animals. For several meat consumers, it is important to know how the farmed chicken raised. Bangka Regency has the highest number of broiler among other regencies in Bangka Belitung Province. Since its high population, chicken farm in Bangka Regency were studied as a case study of how animal welfare is applied in the Province. Aim of this research was to assess the level of animal welfare in five chicken farms in Bangka Regency. Data were collected through interview and observation, then were analysed by a modified Animal Needs Index (ANI) from Bartussek. Several animal welfare categories were movement, social interaction, quality flooring, light and air, and cleanliness. Results showed that ANI index were varied from 14.2 to 16.5 , with an average is 16 . According to the Animal Needs Index (ANI), a score of 16 to $<21$ indicates the quite sufficient of welfare.
\end{abstract}

Keywords: welfare, chicken farms, Bangka

\section{PENDAHULUAN}

Kesejahteraan hewan adalah segala urusan yang berhubungan dengan keadaan fisik dan mental pada hewan menurut perilaku alami hewan yang perlu diterapkan untuk melindungi hewan dari perlakuan setiap orang yang tidak layak terhadap hewan yang dimanfaatkan manusia. Menurut Winarso (2008), perhatian masyarakat terhadap kesejahteraan hewan terus mengalami peningkatan. Kesejahteraan hewan dapat dilihat dari lima kategori yaitu, lokomosi, interaksi sosial, kualitas lantai, cahaya, udara, kebisingan dan kualitas perawatan manusia terhadap hewan. Salah satu hewan ternak yang perlu dilihat tingkat kesejahteraan yaitu ayam ras pedaging.

Kabupaten Bangka merupakan salah satu Kabupaten di Provinsi Kepulauan Bangka Belitung yang memiliki populasi ayam ras pedaging terbesar dibandingkan dengan
Kabupaten lainnya. Jumlah ayam ras pedaging di Kabupaten Bangka yaitu sebanyak 3.162.180 ekor, Pangkalpinang sebanyak 653.719 ekor, Belitung sebanyak 3.023.933 ekor, Bangka Tengah sebanyak 1.249.396 ekor, Bangka Barat sebanyak 296.216 ekor, Bangka Selatan sebanyak 1.647 .968 ekor, Belitung Timur sebanyak 470.810 ekor (BPS 2015).

Keberadaan peternakan ayam ras pedaging di Kabupaten Bangka dipengaruhi oleh kebutuhan masyarakat terhadap protein hewani, sehingga konsumsi daging dapat meningkat. Kesejahteraan ayam ras pedaging akan memberi manfaat bagi kualitas hidup hewan maupun manusia itu sendiri. Oleh karena itu, penelitian ini penting untuk dilakukan untuk meningkatkan kesadaran para peternak agar dapat memperhatikan kesejahteraan ayam ternaknya. Penelitian ini bertujuan untuk mengkaji tingkat kesejahteraan ayam ras 
pedaging pada beberapa peternakan di Kabupaten Bangka. Hasil penelitian diharapkan dapat menjadi informasi bagi peternak mengenai tingkat kesejahteraan ayam ras pedaging di Kabupaten Bangka.

\section{BAHAN DAN METODE}

\section{Waktu dan Tempat}

Pengambilan data dilaksanakan pada bulan September-Oktober 2015, penelitian dilakukan di Kabupaten Bangka yang terdiri dari beberapa peternakan di Kabupaten Bangka yaitu di Kecamatan Merawang (Desa Balunijuk dan Desa Pagarawan) di Kecamatan Mendo Barat (Desa Petaling dan Desa Paya Benua) dan Kota Sungailiat (Desa Rambak). Jumlah peternakan yang dijadikan sampel penelitian adalah 5 . Peternakan dipilih dengan menggunakan metode purposive sampling yaitu teknik pengambilan data dengan pertimbangan peneliti. Kriteria peternakan yang dipilih yaitu beternak ayam minimal 3 tahun, jumlah ayam minimal 1000 ekor per kandang. Data peternakan ayam ras pedaging di Kabupaten Bangka disajikan pada Tabel 1.

Tabel 1. Peternakan Ayam Ras Pedaging di Kabupaten Bangka

\begin{tabular}{clll}
\hline $\begin{array}{c}\text { Peternak } \\
\text { an }\end{array}$ & Alamat & $\begin{array}{c}\text { Umur } \\
\text { ayam }\end{array}$ & $\begin{array}{c}\text { Jumlah } \\
\text { ayam } \\
\text { (ekor) }\end{array}$ \\
\hline A & Paya Benua & 2 minggu & 1000 \\
B & Petaling & 3 minggu & 5700 \\
C & Pagarawan & 1 minggu & 2500 \\
D & Balunijuk & 1 minggu & 1200 \\
E & Rambak & 3 minggu & 2050 \\
\hline
\end{tabular}

Ket. (A) peternakan Bapak Bian, (B) peternakan Bapak Aling, (C) peternakan Bapak Edi, (D) peternakan Bapak Bambang, dan (E) peternakan Bapak Anggie.

\section{Alat dan Bahan}

Alat yang digunakan adalah alat perekam, alat tulis, kamera digital, kuesioner dan panduan penilaian Animal Needs Index (ANI).

\section{Metode Penelitian \\ Survei Pendahuluan}

Survei pertama kali dilakukan di dinas Peternakan dan Kelautan Kabupaten Bangka yang didapatkan data Kecamatan Merawang, Mendo Barat dan Kota Sungailiat merupakan Kecamatan terbanyak yang memelihara ayam ras pedaging. Kemudian survei dilakukan di Balai pertanian untuk mengetahui Desa terbanyak yang memelihara ayam ras pedaging. Setelah didapatkan hasil di lakukan survei ke peternakan untuk mengetahui kondisi peternakan (pemberian pakan, minum, vitamin, mengetahui jumlah ayam dalam satu kandang dan juga lama beternak) dan melakukan pendekatan/pengenalan kepada para peternak sebelum diwawancarai.

\section{Pengumpulan Data}

Data diperoleh melalui wawancara dan pengamatan.

1. Wawancara: Pengumpulan informasi dilakukan dengan sistem wawancara terstruktur (Sugiono 2012). Wawancara yang dilaksanakan secara terencana dengan berpedoman pada daftar pertanyaan yang telah dipersiapkan.

2. Pengamatan: Pengamatan dilakukan dengan mengacu modifikasi dari Animal Needs Index yang dilihat dari luas kandang. Pada metode ANI (Bartussek 2001) luas kandang dinyatakan dalam ekor $/ \mathrm{m}^{2}$, dalam penelitian ini dimodifikasi menjadi $\mathrm{m}^{2} / \mathrm{ekor}$. ANI menggunakan sistem penilaian dengan lima kategori.

a. Lokomosi: luas kandang, luas daerah menggaruk, ketinggian tempat bertengger, jumlah hari di luar/tahun, jarak kandang dari padang rumput dan halaman luar.

b. Interaksi sosial: ukuran kawanan yang terpisah, fasilitas di halaman, ketersediaan pakan dan minum, ketersediaan tempat bertengger, lebar bukaan pintu keluar dan jarak bukaan pintu keluar.

c. Kualitas lantai: penutup kotoran, kualitas bertengger, alas di dalam kandang, lantai di luar kandang, kondisi rumput dan kondisi alas.

d. Cahaya, Udara dan Kebisingan: cahaya di dalam kandang, kualitas udara, latihan di luar jam/hari, latihan 
di luar hari/tahun, kebisingan dan penyediaan naungan di luar kandang.

e. Kualitas perawatan manusia terhadap hewan: kebersihan peralatan, kondisi peralatan, bangkai di dalam kandang, kondisi bulu, kondisi kulit, dan kesehatan ayam.

Pengambilan data dilakukan sebanyak tiga kali ulangan pada tiga waktu yang berbeda. Nilai dari lima kategori tersebut kemudian dirangkum untuk melihat total skor untuk semua kategori.

\section{Analisis data}

Data yang telah didapatkan dari hasil wawancara dan pengamatan langsung di lapangan diolah dan dianalisis dengan menggunakan metode Bartussek (2001) yang dimodifikasi, disajikan dalam bentuk uraian dan tabel.

\section{HASIL DAN PEMBAHASAN}

Hasil

Tingkat kesejahteraan ayam ras pedaging dapat dilihat dari beberapa kategori yaitu lokomosi, interaksi sosial, kualitas lantai, cahaya, udara, kebisingan dan kualitas perawatan manusia terhadap hewan.

\section{Kategori Lokomosi}

Penilaian kesejahteraan yang terkait dengan lokomosi meliputi luas kandang, luas daerah menggaruk, ketinggian tempat bertengger, jumlah hari di luar/tahun, jarak kandang dari padang rumput dan halaman luar. Jumlah hari di luar/tahun dan halaman luar tidak ada nilai karena pada peternakan ayam ras pedaging tidak ada aktivitas di luar kandang. Skor rata-rata kategori lokomosi untuk kesejahteraan ayam ras pedaging di Kabupaten Bangka ditunjukkan pada Tabel 2.

Skor penilaian rata-rata untuk luas kandang pada setiap peternakan adalah 0,5 (Tabel 2/a1), sementara rata-rata ayam ras pedaging di Kabupaten Bangka dapat menampung $9 \mathrm{ekor} / \mathrm{m}^{2}$ (Tabel 3). Hal ini sesuai dengan panduan penilaian lokomosi metode Animal Needs Index, dimana skor penilaian lokomosi dengan rentang 0,5-0,9 dapat menampung ayam ras pedaging $\left(>8 \mathrm{ekor} / \mathrm{m}^{2}\right)$.
Tabel 2 Penilaian kesejahteraan hewan di Kabupaten Bangka dilihat dari kategori lokomosi

\begin{tabular}{ccccccc}
\hline & \multicolumn{5}{c}{ Peternakan } & $\begin{array}{c}\text { Skor } \\
\text { Kategori I }\end{array}$ \\
\cline { 2 - 6 } & $\mathrm{A}$ & $\mathrm{B}$ & $\mathrm{C}$ & $\mathrm{D}$ & $\mathrm{E}$ & $\begin{array}{c}\text { Rata- } \\
\text { rata }\end{array}$ \\
\hline a1 & 0,5 & 0,5 & 0,5 & 0,5 & 0,5 & 0,5 \\
b1 & 1,0 & 1,0 & 1,0 & 1,0 & 1,0 & 1,0 \\
c1 & $-0,5$ & $-0,5$ & $-0,5$ & $-0,5$ & $-0,5$ & $-0,5$ \\
d1 & - & - & - & - & - & - \\
e1 & 0,5 & 0 & 0,5 & 0 & 0 & 0,2 \\
f1 & - & - & - & - & - & - \\
\hline Skor total & 1,5 & 1,0 & 1,5 & 1,0 & 1,0 & 1,2 \\
\hline
\end{tabular}

Ket.(Kategori I) lokomosi, (a1) luas kandang, (b1) luas daerah menggaruk, (c1) ketinggian tempat bertengger, (d1) jumlah hari di luar/tahun, (e1) jarak kandang dari padang rumput, (f1) halaman luar. (A) peternakan Bapak Bian, (B) peternakan Bapak Aling, (C) peternakan Bapak Edi, (D) peternakan Bapak Bambang, dan (E) peternakan Bapak Anggie.

Tabel 3 Jumlah ayam per luas kandang pada peternakan ayam ras pedaging di Kabupaten Bangka

\begin{tabular}{cccc}
\hline Peternakan & $\begin{array}{c}\text { Jumlah } \\
\text { ayam } \\
\text { (ekor) }\end{array}$ & $\begin{array}{c}\text { Luas } \\
\text { kandang } \\
\left(\mathrm{m}^{2}\right)\end{array}$ & $\begin{array}{c}\sum \\
\text { ekor }\end{array}$ \\
\hline A & 1000 & 90 & 11 \\
B & 5700 & 560 & 10 \\
C & 2500 & 400 & 6 \\
D & 1200 & 120 & 10 \\
E & 2050 & 200 & 10 \\
\hline Rata-rata & & & 9 \\
\hline
\end{tabular}

Ket. (A) peternakan Bapak Bian, (B) peternakan Bapak Aling, (C) peternakan Bapak Edi, (D) peternakan Bapk Bambang, dan (E) peternakan Bapak Anggie.

Pengamatan skor rata-rata penilaian luas daerah menggaruk pada setiap peternakan adalah 1,0 (Tabel 2/b1), sementara rata-rata luas daerah menggaruk $>50 \%$ dari luas lantai. Hal ini sesuai dengan panduan penilaian lokomosi metode Animal Needs Index, dimana skor penilaian lokomosi dengan rentang 1,0-1,4 luas daerah menggaruk $>50 \%$ dari luas lantai.

Nilai rata-rata ketinggian tempat bertengger skor $-0,5$ (Tabel 2/c1). Penilaian Animal Needs Index (ANI) menunjukkan bahwa pada seluruh peternakan ayam ras pedaging tidak menyediakan tempat bertengger. 
Berdasarkan hasil pengamatan rata-rata jarak kandang ayam ras pedaging dari padang rumput pada seluruh peternakan ayam ras pedaging skor 0,2 (Tabel 2/e1). Penilaian Animal Needs Index (ANI) menunjukkan bahwa jarak kandang dari padang rumput $\geq 2,5 \mathrm{~m}$. Hal tersebut sesuai dengan hasil wawancara, ratarata jarak kandang dari padang rumput pada peternakan $\mathrm{B}, \mathrm{D}$ dan $\mathrm{E}$ yaitu $\geq 2,5 \mathrm{~m}$, sedangkan pada peternakan $\mathrm{A}$, dan $\mathrm{C}$ yaitu $\geq 5,0 \mathrm{~m}$.

\section{Kategori Interaksi Sosial}

Penilaian kesejahteraan yang terkait dengan interaksi sosial meliputi ukuran kawan yang terpisah, fasilitas di halaman, ketersediaan pakan dan minum, ketersediaan tempat bertengger, lebar bukaan pintu keluar dan jarak bukaan pintu keluar. Skor rata-rata kategori interaksi sosial untuk kesejahteraan ayam ras pedaging di Kabupaten Bangka ditunjukkan pada Tabel 4.

Tabel 4 Penilaian kesejahteraan hewan di Kabupaten Bangka dilihat dari kategori interaksi sosial

\begin{tabular}{|c|c|c|c|c|c|c|}
\hline \multirow{2}{*}{ Kategori II } & \multicolumn{5}{|c|}{ Peternakan } & \multirow{2}{*}{$\begin{array}{l}\text { Skor } \\
\text { Rata- } \\
\text { rata }\end{array}$} \\
\hline & $\mathrm{A}$ & B & $\mathrm{C}$ & $\mathrm{D}$ & $\mathrm{E}$ & \\
\hline $\mathrm{a} 2$ & 1,1 & 1,0 & 1,1 & 1,2 & 1,0 & 1,1 \\
\hline b2 & - & - & - & & - & - \\
\hline $\mathrm{c} 2$ & 1,0 & 0,6 & 1,1 & 1,2 & 1,3 & 1,0 \\
\hline $\mathrm{d} 2$ & 0 & 0 & 0 & 0 & 0 & 0 \\
\hline e2 & - & - & - & - & - & - \\
\hline $\mathrm{f} 2$ & - & - & - & - & - & - \\
\hline Skor total & 2,1 & 1,6 & 2,2 & 2,4 & 2,3 & 2,1 \\
\hline
\end{tabular}

Ket. (Kategori II) interaksi sosial, (a2) ukuran kawanan yang terpisah, (b2) fasilitas di halaman, (c2) ketersediaan pakan dan minum, (d2) ketersediaan tempat bertengger, (e2) lebar bukaan pintu keluar, (f2) jarak bukaan pintu keluar. (A) peternakan Bapak Bian, (B) peternakan Bapak Aling, (C) peternakan Bapak Edi, (D) peternakan Bapak Bambang, dan (E) peternakan Bapak Anggie.

Rata-rata ukuran kawanan yang terpisah pada seluruh peternakan memiliki skor 1,1 (Tabel 4/a2). Berdasarkan hasil wawancara dan penilaian Animal Needs Index (ANI) menunjukkan bahwa pada seluruh peternakan ayam ras pedaging di Kabupaten Bangka memiliki jumlah kawanan yang terpisah lebih dari 200 ekor.

Rata-rata ketersediaan pakan dan minum pada seluruh peternakan memiliki skor 1,1 (Tabel 4/c2). Penilaian Animal Needs Index (ANI) menunjukkan bahwa ketersediaan pakan dan minum pada seluruh peternakan ayam ras pedaging dikategorikan baik. Semakin tinggi skor, maka semakin baik ketersediaan pakan dan minum. Nilai tertinggi dimiliki oleh peternakan E, sedangkan nilai terendah dimiliki oleh peternak B. Hal tersebut menunjukkan ketersediaan pakan dan minum pada peternak E sangat baik, sedangkan pada peternak B sedang. Ketersediaan pakan dan minum selalu tersedia maka semakin baik kesejahteraan ayam ras pedaging.

Rata-rata ketersediaan tempat bertengger memiliki skor 0 (Tabel 4/d2). Penilaian Animal Needs Index (ANI) menunjukkan bahwa bahwa pada seluruh peternakan ayam ayam ras pedaging di Kabupaten Bangka tidak ada yang menyediakan tempat bertengger.

\section{Kategori Kualitas Lantai}

Penilaian kesejahteraan yang terkait dengan kualitas lantai meliputi penutup kotoran, kualitas bertengger, alas di dalam kandang, lantai di luar kandang, kondisi rumput dan kondisi alas. Namun, penilaian untuk kualitas bertengger, penutup kotoran dan lantai di luar kandang tidak ada nilai. Rata-rata penilaian kualitas lantai untuk kesejahteraan ayam ras pedaging di kabupaten Bangka ditunjukkan pada Tabel 5.

Rata-rata alas di dalam kandang pada peternakan memiliki skor 1,5 (Tabel 5/c3). Berdasarkan hasil wawancara dan penilaian Animal Needs Index (ANI) menunjukkan bahwa lantai yang digunakan pada peternakan ayam ras pedaging di Kabupaten Bangka adalah sekam.

Rata-rata kondisi rumput di sekitar kandang memiliki skor 0,6 (Tabel 5/e3). Penilaian Animal Needs Index (ANI) menunjukkan bahwa kondisi rumput di sekitar kandang ayam ras pedaging dikategorikan sedang. Pada peternakan C dan D memiliki skor lebih tinggi dibandingkan peternak lainnya. Hal tersebut menunjukkan bahwa pada peternakan 
C dan D memiliki kondisi rumput lebih baik dibanding peternakan lainnya.

Tabel 5 Penilaian kesejahteraan hewan di Kabupaten Bangka dilihat dari kategori kualitas lantai

\begin{tabular}{ccccccc}
\hline \multirow{2}{*}{$\begin{array}{c}\text { Kategori } \\
\text { III }\end{array}$} & A & B & C & D & E & $\begin{array}{c}\text { Skor } \\
\text { Rata- } \\
\text { rata }\end{array}$ \\
\cline { 2 - 6 } a3 & - & - & - & - & - & - \\
b3 & - & - & - & - & - & - \\
c3 & 1,5 & 1,5 & 1,5 & 1,5 & 1,5 & 1,5 \\
d3 & - & - & - & - & - & - \\
e3 & 0,5 & 0,5 & 0,7 & 0,7 & 0,5 & 0,6 \\
f3 & 1,5 & 1,3 & 1,2 & 1,4 & 1,0 & 1,3 \\
\hline Skor total & 3,5 & 3,3 & 3,4 & 3,6 & 3,0 & 3,4 \\
\hline Ket. (Kategnannn
\end{tabular}

Ket.(Kategori III) kualitas lantai, (a3) penutup kotoran, (b3) kualitas bertengger, (c3) alas di dalam kandang, (d3) lantai di luar kandang, (e3) kondisi rumput, (f3) kondisi alas. (A) peternakan Bapak Bian, (B) peternakan Bapak Aling, (C) peternakan Bapak Edi, (D) peternakan Bapak Bambang, dan (E) peternakan Bapak Anggie.

Rata-rata pengamatan kondisi alas pada peternakan memiliki skor 1,3 (Tabel 5/f3). Penilaian Animal Needs Index (ANI) menunjukkan bahwa kondisi alas pada peternakan ayam ras pedaging di Kabupaten Bangka yaitu kering hingga 30\%. Skor tertinggi terdapat pada peternakan A yang menunjukkan bahwa kondisi alas kering, dan terdapat bulu ayam di area kandang.

\section{Kategori Cahaya, Udara dan Kebisingan}

Penilaian kesejahteraan yang terkait dengan cahaya udara dan kebisingan meliputi cahaya dalam kandang, kualitas udara, latihan di luar jam/hari, latihan di luar hari/tahun, kebisingan, dan penyediaan naungan di luar kandang. Skor rata-rata kategori cahaya, udara dan kebisingan untuk kesejahteraan ayam ras pedaging di Kabupaten Bangka ditunjukkan pada Tabel 6.

Rata-rata pengamatan cahaya di dalam kandang memiliki skor 1,2 (Tabel 6/a4). Penilaian Animal Needs Index (ANI) menunjukkan bahwa pada siang hari kondisi cahaya dalam kandang terang. Peternakan A dan E memiliki rentang skor yang lebih tinggi dibandingkan peternakan B, C, dan D. Hal tersebut menunjukkan bahwa pada siang hari kondisi cahaya dalam kandang peternakan A dan $\mathrm{E}$ lebih terang dibandingkan peternak B, C, dan D.

Tabel 6 Penilaian kesejahteraan hewan di Kabupaten Bangka dilihat dari kategori cahaya, udara dan kebisingan

\begin{tabular}{ccccccc}
\hline \multirow{2}{*}{$\begin{array}{c}\text { Kategori } \\
\text { IV }\end{array}$} & A & B & C & D & E & $\begin{array}{c}\text { Skor } \\
\text { Rata- } \\
\text { rata }\end{array}$ \\
\cline { 2 - 7 } a4 & 1,5 & 1,1 & 1,1 & 0,9 & 1,5 & 1,2 \\
b4 & 1,5 & 1,5 & 1,2 & 1,3 & 1,0 & 1,3 \\
c4 & 0,8 & 0,6 & 1,0 & 1,0 & 1,0 & 0,9 \\
d4 & - & - & - & - & - & - \\
e4 & - & - & - & - & - & - \\
f4 & - & - & - & - & - & - \\
\hline Skor total & 3,8 & 3,2 & 3,3 & 3,2 & 3,5 & 3,4 \\
\hline
\end{tabular}

Ket.(Kategori IV) cahaya, udara dan kebisingan, (a4) cahaya dalam kandang, (b4) kualitas udara, (c4) kebisingan, (d4) Latihan di luar jam/hari, (e4) Latihan di luar hari/tahun, (f4) penyediaan naungan di luar kandang. (A) peternakan Bapak Bian, (B) peternakan Bapak Aling, (C) peternakan Bapak Edi, (D) peternakan Bapak Bambang, dan (E) peternakan Bapak Anggie.

Rata-rata kualitas udara memiliki skor 1,3 (Tabel 6/b4). Penilaian Animal Needs Index (ANI) menunjukkan kualitas udara pada seluruh peternakan dikategorikan cukup baik. Peternakan A dan B memiliki skor lebih tinggi dibandingkan peternakan C, D, dan E. Hal tersebut menunjukkan kualitas udara pada peternakan A dan B sangat baik dibandingkan dengan peternakan lainnya.

Rata-rata tingkat kebisingan seluruh peternakan memiliki skor 0,9 (Tabel 6/c4). Penilaian Animal Needs Index (ANI) menunjukkan bahwa tingkat kebisingan di peternakan ayam ras pedaging terdengar suara tidak jelas. Rata-rata pada peternakan C, D, dan E memiliki skor $(1,0)$. Berdasarkan penilaian ANI dalam kategori tingkat kebisingan peternakan $\mathrm{C}, \mathrm{D}$ dan $\mathrm{E}$ tidak ada suara.

\section{Kategori Kualitas Perawatan Manusia terhadap Hewan}

Penilaian kesejahteraan yang terkait dengan kualitas perawatan terhadap hewan meliputi kebersihan dan kondisi peralatan, 
bangkai di dalam kandang, kondisi kulit, bulu ayam dan juga kesehatan ayam. Skor rata-rata kategori kualitas perawatan manusia terhadap hewan untuk kesejahteraan ayam ras pedaging di Kabupaten Bangka ditunjukkan pada Tabel 7.

Tabel 7 Penilaian kesejahteraan hewan di Kabupaten Bangka dilihat dari kategori kualitas perawatan manusia terhadap hewan

\begin{tabular}{ccccccc}
\hline \multirow{2}{*}{$\begin{array}{c}\text { Kategori } \\
\text { V }\end{array}$} & $\mathrm{A}$ & $\mathrm{B}$ & $\mathrm{C}$ & $\mathrm{D}$ & $\mathrm{E}$ & $\begin{array}{c}\text { Skor } \\
\text { Rata- } \\
\text { rata }\end{array}$ \\
\cline { 2 - 6 } a5 & 1,0 & 1,0 & 1,0 & 1,0 & 1,0 & 1,0 \\
b5 & 1,0 & 1,0 & 1,0 & 1,0 & 1,0 & 1,0 \\
c5 & 0,6 & 0,3 & 0,6 & 0,8 & 1,0 & 0,7 \\
d5 & 1,0 & 1,0 & 1,0 & 1,0 & 1,0 & 1,0 \\
e5 & 1,0 & 1,0 & 1,0 & 1,0 & 1,0 & 1,0 \\
f5 & 1,0 & 0,8 & 0,6 & 1,0 & 1,0 & 0,9 \\
\hline Skor total & 5,6 & 5,1 & 5,2 & 5,8 & 6,0 & 5,5 \\
\hline
\end{tabular}

Ket.(Kategori V) kualitas perawatan manusia terhadap hewan, (a5) kebersihan peralatan, (b5) kondisi peralatan, (c5) bangkai di dalam kandang, (d5) kondisi bulu, (e5) kondisi kulit, (f5) kesehatan ayam. A) peternakan Bapak Bian, (B) peternakan Bapak Aling, (C) peternakan Bapak Edi, (D) peternakan Bapak Bambang, dan (E) peternakan Bapak Anggie.

Rata-rata pengamatan kebersihan dan kondisi peralatan seluruh peternakan skor 1,0 (Tabel 7/a5 dan b5). Penilaian Animal Needs Index (ANI) menunjukkan bahwa kebersihan dan kondisi peralatan dikategorikan bersih dan baik.

Rata-rata bangkai di dalam kandang pada seluruh peternakan memiliki skor 0,7 (Tabel 7/c5). Penilaian Animal Needs Index (ANI) menunjukkan bahwa pada beberapa peternakan tidak ditemukan bangkai ayam. Skor tetinggi terdapat pada peternakan E yang menunjukkan bahwa tidak ada satupun bangkai di kandang. Skor terendah yaitu pada petenakan B yang menunjukkan bahwa terdapat beberapa bangkai ayam yang masih baru di dalam kandang.

Rata-rata pengamatan kondisi bulu dan kulit ayam pada peternakan skor 1,0 (Tabel 7/d5 dan e5). Penilaian Animal Needs Index (ANI) menunjukkan bahwa skor kondisi bulu dan kulit ayam dikategorikan baik.
Rata-rata pengamatan kesehatan ayam pada seluruh peternakan skor 0,9 (Tabel 7/f5). Penilaian Animal Needs Index (ANI) menunjukkan bahwa kondisi kesehatan ayam cukup baik. Pada peternakan A, D, dan E memiliki skor lebih tinggi dibandingkan peternakan $\mathrm{B}$, dan $\mathrm{C}$. Hal tersebut menunjukkan bahwa peternakan $\mathrm{A}, \mathrm{D}$, dan $\mathrm{E}$ memiliki kesehatan ayam yang lebih baik dibandingkan peternakan $\mathrm{B}$, dan $\mathrm{C}$.

\section{Animal Needs index (ANI)}

Rata-rata skor total seluruh peternakan ayam ras pedaging di Kabupaten Bangka memiliki skor 16 (Tabel 8). Menurut penilaian Animal Needs Index (ANI), skor 16-<21 menunjukkan kesejahteraan ayam ras pedaging yaitu (31-50\%) cukup sejahtera. Namun, ratarata skor total pada peternakan B menunjukkan skor paling rendah yaitu 14,2 (Tabel 8), skor 11-<16 menunjukkan ayam ras pedaging dikategorikan kurang sejahtera.

Tabel 8 Skor total seluruh peternakan ayam ras pedaging di Kabupaten Bangka

\begin{tabular}{|c|c|c|c|c|c|c|}
\hline \multirow{2}{*}{ Kategori } & \multicolumn{5}{|c|}{ Peternakan } & \multirow{2}{*}{$\begin{array}{l}\text { Skor } \\
\text { Rata } \\
\text {-rata }\end{array}$} \\
\hline & $\mathrm{A}$ & $\mathrm{B}$ & $\mathrm{C}$ & $\mathrm{D}$ & $\mathrm{E}$ & \\
\hline I & 1,5 & 1,0 & 1,5 & 1,0 & 1,0 & 1,2 \\
\hline II & 2,1 & 1,6 & 2,2 & 2,4 & 2,3 & 2,1 \\
\hline III & 3,5 & 3,3 & 3,4 & 3,6 & 3,0 & 3,4 \\
\hline IV & 3,8 & 3,2 & 3,3 & 3,2 & 3,5 & 3,4 \\
\hline V & 5,6 & 5,1 & 5,2 & 5,8 & 6,0 & 5,5 \\
\hline Skor total & 16,5 & 14,2 & 15,6 & 16 & 15,8 & 16 \\
\hline
\end{tabular}

Ket.(A) peternakan Bapak Bian, (B) peternakan Bapak Aling, (C) peternakan Bapak Edi, (D) peternakan Bapak Bambang, dan (E) peternakan Bapak Anggie.

\section{PEMBAHASAN}

\section{Kategori Lokomosi}

Kesejahteraan ayam ras pedaging pada beberapa peternakan di Kabupaten Bangka dilihat dari kategori lokomosi untuk beberapa subkategori, skor yang diperoleh sudah cukup baik. Salah satu kategori yang penting untuk diperhatikan pada kategori lokomosi adalah luas kandang. Luas kandang dapat mempengaruhi pertumbuhan dan kesehatan ayam ras pedaging. 
Luas kandang peternakan di Kabupaten Bangka dapat menampung 9 ekor $/ \mathrm{m}^{2}$. Firmansyah (2015) menyatakan bahwa kepadatan kandang yang ideal untuk ayam ras pedaging adalah 8-10 ekor $/ \mathrm{m}^{2}$. Hal tersebut menunjukkan bahwa peternakan di Kabupaten Bangka tergolong ideal. Kepadatan kandang yang ideal dapat membantu pertumbuhan ayam dikarenakan tidak terjadi persaingan untuk mendapatkan pakan dan air minum maupun oksigen. Berdasarkan hasil wawancara untuk luas kandang pada seluruh peternakan rata-rata memiliki luas kandang yang cukup ideal karena lokomosi ayam di dalam kandang cukup bagus.

Luas daerah menggaruk pada ayam ras pedaging yaitu $>50 \%$ dari luas lantai. Hal tersebut menunjukkan bahwa daerah menggaruk tersebut ideal. Menurut (Bartussek 2001), luas daerah menggaruk yang ideal yaitu $>50 \%$ dari luas lantai, semakin tinggi persentase daerah menggaruk maka semakin bagus.

Ketinggian tempat bertengger tidak ada nilai dikarenakan seluruh peternakan ayam ras pedaging tidak menyediakan tempat bertengger. Standar nilai yang baik untuk ketinggian tempat bertengger adalah 1,0 yang menunjukkan ketinggian tempat bertengger $(>0,08 \mathrm{~m})$.

Jarak kandang dari padang rumput pada peternakan ayam ras pedaging di Kabupaten Bangka yaitu $>5,0 \mathrm{~m}$. Hal tersebut menunjukkan bahwa jarak tersebut cukup dekat. Menurut (Bartussek 2001), jarak kandang dari padang rumput minimal $>1,0 \mathrm{~m}$, sedangkan standar yang baik yaitu $<15 \mathrm{~m}$. Jarak kandang yang terlalu dekat kurang baik untuk kesejahteraan ayam ras pedaging. Hal tersebut diperkuat Sholikin (2011), bahwa jarak kandang yang terlalu dekat dengan padang rumput dapat mempengaruhi kesehatan ayam ras pedaging. Berdasarkan hasil wawancara rata-rata jarak kandang dari padang rumput cukup dekat yang bisa mempengaruhi kesehatan ayam.

\section{Kategori Interaksi Sosial}

Peternakan ayam ras pedaging di Kabupaten Bangka kurang baik. Hal ini dikarenakan jumlah kawanan lebih dari 200 ekor. Menurut Bartussek (2001), jumlah terbaik untuk ukuran kawanan yang terpisah maksimal 200 ekor. Ukuran kawanan yang lebih dari 200 ekor per sekat akan mempengaruhi kenyamanan dan membuat ayam sulit untuk bergerak dan menjangkau tempat pakan dan minum. Menurut Cintia (2009), sekat digunakan untuk membatasi ruang gerak ayam agar lebih mudah dalam mengatur kondisi lingkungan.

Ketersediaan pakan dan minum pada peternakan A, C, D dan E dikategorikan baik. Hal tersebut dikarenakan pemberian pakan dan minum dilakukan secara ad libitum (terusmenerus). Pertumbuhan dan kesehatan ayam dipengaruhi oleh ketersediaan pakan dan minum. Hal tersebut menunjukkan bahwa pada peternakan A, C, D dan E memiliki pertumbuhan ayam yang lebih baik dibandingkan peternakan B. Berdasarkan hasil wawancara pada peternakan B untuk beberapa hari tidak ada ketersediaan pakan dikarenakan stok pakan habis.

Peternakan ayam ras pedaging di Kabupaten Bangka tidak ada yang meyediakan tempat bertengger. Tempat bertengger biasanya digunakan untuk istirahat. Tempat bertengger pada ayam ras pedaging tidak terlalu dibutuhkan, karena ayam ras pedaging biasanya istirahat di lantai. Berdasarkan hasil wawancara pada seluruh peternakan tidak ada satupun para peternak yang menggunakan tempat bertengger.

\section{Kategori Kualitas Lantai}

Alas di dalam kandang pada beberapa peternakan ayam ras pedaging di Kabupaten Bangka menggunakan sekam. Sekam banyak digunakan karena mudah didapatkan. Penggunaan sekam dikeringkan terlebih dahulu sebelum digunakan karena sekam yang basah bisa menjadi sumber penyakit. Menurut (Tobing 2005 dalam Muharlien et al. 2011), alas kandang harus mempunyai daya serap air yang tinggi sebagai pengontrol kelembaban kandang. Salah satu alas kandang yang mempunyai daya serap tinggi adalah sekam (Rahmawati 2011).

Kategori kualitas lantai terhadap kondisi rumput di sekitar kandang pada peternakan ayam ras pedaging di Kabupaten Bangka kurang diperhatikan oleh para peternak. Hal tersebut dilihat dari kondisi rumput yang kering 
diakibatkan oleh cuaca yang panas, sehingga rumput banyak yang mati.

Kondisi alas pada peternakan ayam ras pedaging di Kabupaten Bangka sudah cukup baik. Kondisi alas pada peternakan A kering dan terdapat bulu ayam di area kandang. Hal tersebut diduga kondisi alas pada peternakan A selalu terjaga dan kering. Hal tersebut menunjukkan bahwa peternakan A memiliki kondisi alas yang dibutuhkan untuk kesehatan dan kesejahteraan ayam.

\section{Kategori Cahaya, Udara dan Kebisingan}

Kesejahteraan ayam ras pedaging dilihat dari cahaya, udara dan kebisingan. Berdasarkan penilaian Animal Needs Index (ANI), kondisi cahaya dalam kandang pada siang hari terang. Pencahayaan akan mempengaruhi peningkatan konsumsi pakan dan minum pada ayam (Sulistyoningsih 2004). Kualitas udara pada peternakan ayam ras pedaging di Kabupaten Bangka sangat baik. Hal tersebut dikarenakan pada seluruh peternakan ayam ras pedaging di Kabupaten Bangka terdapat ventilasi. Ventilasi adalah lokomosi udara yang memungkinkan terjadinya pertukaran udara kotor dan udara segar. Ventilasi yang cukup akan mengurangi panas dan pengap pada kandang. Berdasarkan hasil wawancara ketersediaan ventilasi pada seluruh peternakan dikategorikan cukup.

Kebisingan yang terjadi pada setiap kandang disebabkan dari ventilasi di kandang. Tingkat kebisingan dari lingkungan akan mempengaruhi tingkat stres pada ayam.

\section{Kategori Kualitas Perawatan Manusia terhadap Hewan}

Kebersihan dan kondisi peralatan di Kabupaten Bangka sudah cukup baik. Tingkat kebersihan dan kondisi peralatan akan mempengaruhi kesehatan ayam ras pedaging. Kondisi kesehatan ayam ras pedaging juga dikarenakan penggunaan vitamin yang rutin. Berdasarkan hasil wawancara pada seluruh peternakan tidak ada yang menggunakan vaksin dikarenakan biasanya ayam yang dipelihara sudah diberi vaksin sebelum di pasarkan.

Kondisi bulu dan kulit ayam ras pedaging di Kabupaten Bangka sudah cukup baik, hal tersebut dikarenakan tidak banyak ayam yang mengalami luka/ memar di bagian kulit akibat persaingan mendapakan pakan dan minum.

Pada peternakan di Kabupaten Bangka terdapat beberapa kandang yang terkena penyakit, adapun penyakit yang diderita ayam adalah penyakit pilek dan ngorok. Apabila penyakit tidak dikendalikan, maka ayam tersebut akan terkena penyakit Infeksius coryza (snot). Penyebaran penyakit snot dalam kandang sangat cepat, baik secara langsung (kontak dengan ayam sakit), maupun tidak langsung (melalui air minum, udara, dan peralatan yang tercemar). Gejala penyakit tersebut yang ditandai dengan muka bengkak dan sulit bernapas (Ariyanti \& Supar 2007).

\section{KESIMPULAN}

Kesejahteraan ayam ras pedaging dengan rata-rata skor 16 yang menunjukkan pada seluruh peternakan di Kabupaten Bangka dikategorikan cukup sejahtera. Skor terendah terdapat pada peternakan B yaitu 14,2, sedangkan skor tertinggi terdapat pada peternakan A yaitu 16,5.

\section{DAFTAR PUSTAKA}

Ariyanti T, Supar. 2007. Pengendalian Coryza Infeksius pada Ayam. J Wartazoa 17:4.

Bartussek H. 2001. Animal Needs Index for Laying Hens ANI 35L2001-laying hens. BAL Gumpenstein,Irdning.

BPS. 2015. Kepulauan Bangka Belitung dalam Angka 2015. Badan Pusat Statistik: Pangkalpinang.

Cintia MM. 2009. Mengelola kandang dan peralatan ayam ras pedaging. Pusat Pengembangan dan Pemberdayaan Pendidik dan Tenaga Kependidikan Pertanian: MATA DIKLAT 02.

Dallas S. 2006. Animal Biology and Care. Edisi kedua. Oxford: Blackwell Science.

Firmansyah R. 2015. Ayam Pedaging. http://www.academia.edu. [Paper]. [04 Des 2015].

Ibrahim S, Allaily. 2012. Pengaruh Berbagai Bahan Litter Terhadap Konsentrasi Ammonia Udara Ambient kandang dan Performan Ayam Broiler. $J$ Agripet.12(1):47-51. 
Miradona Y, Novarino W, Rizaldi. 2013. Analisis Pengelolaan untuk Meningkatkan Upaya Konservasi di Taman Margastwa dan Budaya Kinantan Kota Bukittinggi. Jurusan Biologi FMIPA Universitas Andalas, Padang. J BIOLOGIKA 2(1):9-10.

Muharlien, Achmanu, Rachmawati. 2011. Meningkatkan Produksi Ayam Ras Pedaging Melalui Pengaturan Proporsi Sekam, Pasir dan Kapur Sebagai Litter. J Tropika 12(1):38-45.

Rahmawati E. 2011. Evaluasi Kualitas Udara Mikrobiologis dan Pengaruhnya Terhadap Kesehatan Pekerja dan Masyarakat sekitar Peternakan Ayam (Studi Kasus: Peternakan Ayam PT Indocentral Desa Sukatani, Cimanggis, Depok). [Skripsi]. Depok: Jurusan Teknik Lingkungan, Fakultas Teknik Universitas Indonesia Depok.

Rinastiti LA. 2013. Animal Welfare. http://lintang rinastiti.blogspot.co.id/2013/04/animalwelfare.html. [16 Sep 2015]

Satria, DG. 2012. Organisasi PDHI dan Kode Etik. Yogyakarta: FKH-UGM.

Sholikin HWS. 2011. Manajemen Pemeliharaan Ayam Broiler di peternakan UD hadi PS Kecamatan Nguter Kabupaten Sukoharjo.[Skripsi]. Surakarta: Jurusan Agribisnis Peternakan, Fakultas Pertanian Universitas Sebelas Maret Surakarta.
Sugiono. 2012. Memahami Penelitian Kualitatif. Bandung: Alfabeta.

Sulistyoningsih M. 2004. Respon fisiologis dan tingah laku ayam broiler periode starter akibat cekaman temperatur dan awal pemberian pakan yang berbeda. [Tesis]. Semarang: Program Studi Magister Ilmu Ternak Program Pasca Sarjana Fakultas Peternakan Universitas Diponegoro.

Sundrum A, Anderson R, Postler G. 1994. Tiergerechtheitsindex-200. Ein Leitfaden zur Beurteilung von Haltungssystemen für Rinder, Kälber, Legehenen und Schweine. Verlag Kollen, Bonn, Jerman. 211 pp.

Winarso A. 2008. Kajian Kesejahteraan Hewan Ternak dalam Ajaran Agama Buddha, Hindu, Yahudi, Nasrani, dan Islam. [Skripsi]. Bogor: Fakultas Kedokteran Hewan Institut Pertanian Bogor.

Yemima. 2014. Analisis Usaha Peternakan Ayam Broiler pada Peternakan Rakyat di Desa Karya Bakti, Kecamatan Rungan, Kabupaten Gunung Mas, Provinsi Kalimantan Tengah. J Ilmu Hewani Tropika 3(1):2301-7783.

Yunus R. 2009. Analisis Efisiensi Usaha Peternakan Ayam Ras Pedaging Pola Kemitraan dan Mandiri di Kota Palu Provinsi Sulawesi Tengah. [Tesis]. Semarang: Universitas Dipenogoro. 